\title{
C-1-Tetrahydrofolate Synthase, Cytoplasmic
}

National Cancer Institute

\section{Source}

National Cancer Institute. C-1-Tetrahydrofolate Synthase, Cytoplasmic. NCI Thesaurus.

Code C104923.

C-1-tetrahydrofolate synthase, cytoplasmic (935 aa, $102 \mathrm{kDa}$ ) is encoded by the human MTHFD1 gene. This protein plays a role in folic acid metabolism. 